\title{
PENERAPAN DOKTRIN PENYALAHGUNAAN KEADAAN (UNDUE INFLUENCE) SEBAGAI ALASAN PEMBATALAN PERJANJIAN KERJA DI PENGADILAN HUBUNGAN INDUSTRIAL ${ }^{1}$
}

\author{
Nabiyla Risfa Izzati \\ Fakultas Hukum Universitas Gadjah Mada \\ Jalan Sosio Justisia Nomor 1, Bulaksumur, Sleman, Daerah Istimewa Yogyakarta \\ nabiylarisfa@ugm.ac.id
}

\begin{abstract}
This article aims to examine the application of the undue influence concept as a reason for revoking an employment agreement in the Industrial Relations Court. Undue influence is a doctrine that has been developed by judges in court, for cases where the position of the two parties to the dispute is unequal. Since the position of workers and employers is not equal, there is a great potential for undue influence in the employment agreement. This study uses a normative legal research method, with qualitative method for data analysis. The result showed that the Industrial Relations Court had been handle cases related with undue influence several times. The author analyses Bandung Industrial Relations Court Decision Number 59/G/2014/PHI.PN.BDG in which the judge use undue influence doctrine for consideration on their decision making process.
\end{abstract}

Keywords: Employment Agreement; Undue Influence; Industrial Relation Court

\begin{abstract}
Abstrak
Artikel ini bertujuan mengkaji penerapan konsep penyalahgunaan keadaan sebagai alasan pembatalan perjanjian kerja di Pengadilan Hubungan Industrial. Penyalahgunaan keadaan merupakan doktrin yang banyak dikembangkan oleh hakim di pengadilan dalam perkara-perkara yang mana kedudukan kedua belah pihak yang bersengketa tidak setara. Karena kedudukan pekerja dan pengusaha dalam perjanjian kerja tidak setara, maka karena terdapat potensi besar terjadinya penyalahgunaan keadaan. Penelitian ini menggunakan metode penelitian hukum yang bersifat normatif, dengan metode kualitatif untuk analisis data. Hasil penelitian menunjukkan bahwa Pengadilan Hubungan Industrial telah beberapa kali menangani kasus terkait dengan ajaran penyalahgunaan keadaan. Penulis menganalisis satu putusan secara spesifik, yakni Putusan Pengadilan Hubungan Industrial Bandung Nomor 59/G/2014/PHI.PN.BDG, yang di dalamnya majelis hakim menjadikan doktrin penyalahgunaan keadaan sebagai bahan pertimbangan dalam mengambil keputusan.
\end{abstract}

Kata Kunci: Perjanjian Kerja; Penyalahgunaan Keadaan; Pengadilan Hubungan Industrial

\footnotetext{
${ }^{1}$ Merupakan artikel hasil penelitian.
} 


\section{A. Pendahuluan}

Perjanjian kerja didefinisikan UndangUndang Nomor 13 Tahun 2003 tentang Ketenagakerjaan sebagai perjanjian antara pekerja/buruh dengan pengusaha atau pemberi kerja yang memuat syarat-syarat kerja, hak, dan kewajiban para pihak. Sebagaimana perjanjian pada umumnya, perjanjian kerja harus dibuat dengan memenuhi empat syarat, yakni: kesepakatan kedua belah pihak; (2) kemampuan atau kecakapan melakukan perbuatan hukum; (3) adanya pekerjaan yang diperjanjikan; dan (4) pekerjaan yang diperjanjikan tidak bertentangan dengan ketertiban umum, kesusilaan, dan peraturan yang berlaku. Keempat syarat ini bersifat kumulatif, artinya, tidak dipenuhinya salah satu syarat saja dapat membawa akibat perjanjian kerja tersebut dapat dibatalkan ataupun batal demi hukum.

Kesepakatan kedua belah pihak merupakan syarat perjanjian kerja yang menarik untuk dibahas lebih mendalam. Kata sepakat merupakan syarat yang sangat esensial dalam perjanjian apapun, karena tanpa adanya kata sepakat maka tidak akan lahir suatu perjanjian (Adhyaksa, 2016; Rahman et al., 2011). Pengertian sepakat dilukiskan sebagai pernyataan kehendak yang disetujui (overeenstemende wilsverklaring) antara pihak-pihak yang membuat perjanjian. Syarat ini mengisyaratkan bahwa kebebasan kehendak para pihak yang membuat perjanjian merupakan sebuah keniscayaan yang harus dipenuhi dalam perjanjian, agar tercipta sebuah kesepakatan yang bebas. Para pihak tidak boleh mendapatkan tekanan apapun yang dapat mengakibatkan cacatnya sebuah kesepakatan bebas (Badrulzaman, 1981).

Kitab Undang-Undang Hukum Perdata mengatur bahwa terdapat tiga hal yang dapat dijadikan alasan untuk membatalkan suatu perjanjian terkait dengan cacatnya kesepakatan bebas, yakni karena adanya kekhilafan/kesesatan (dwaling), paksaan (dwang), dan penipuan (bedrog). Seiring dengan perkembangan hukum perdata, muncul satu alasan lagi yang dapat dijadikan landasan untuk membatalkan perjanjian, yakni penyalahgunaan keadaan (undue influence; misbruik van omstanddigheden) (Bakker, 2016; van Eck, 1999)

Penyalahgunaan keadaan adalah sebuah ajaran/doktrin yang muncul pertama kali di Inggris pada abad ke-15 dengan istilah undue influence. Ajaran undue influence ini mulai berkembang secara signifikan dan digunakan sebagai dasar pertimbangan hakim di Inggris pada abad ke-19 (Hernoko \& Anand, 2017). Doktrin ini banyak dikembangkan oleh hakim di pengadilan dalam perkara-perkara yang mana kedudukan kedua belah pihak yang bersengketa tidak setara, dalam artian salah satu pihak memiliki kuasa yang lebih besar terhadap pihak yang lain. Ajaran undue influence kemudian muncul guna memastikan bahwa pengaruh satu pihak atas pihak lain tidak disalahgunakan (Enonchong, 1996).

Asikin Kusumah Atmadja mendefinisikan penyalahgunaan keadaan sebagai faktor yang membatasi atau mengganggu adanya kehendak yang bebas untuk menentukan persetujuan antara kedua pihak. Penyalahgunaan keadaan pada dasarnya terdiri dari dua unsur, yaitu menimbulkan kerugian yang sangat besar bagi salah satu pihak serta menyalahgunakan kesempatan (Nurhayati, 2019). Meskipun penyalahgunaan keadaan belum diatur dalam KUHPerdata maupun peraturan perundang-undangan lain di Indonesia, praktik peradilan Indonesia sebenarnya telah menerapkan ajaran misbruik van omstandiheden ini, meski masih sangat terbatas (Hernoko \& Anand, 2017). Artinya, meski belum diatur secara tertulis, namun ajaran penyalahgunaan keadaan bukanlah hal yang asing di Indonesia.

Doktrin penyalahgunaan keadaan sangat menarik untuk dikaji dari kacamata hukum ketenagakerjaan dan perjanjian kerja, karena perjanjian kerja merupakan salah satu jenis perjanjian yang di dalam pembuatannya rawan terjadi penyalahgunaan keadaan. F.X Djumialdi, ahli hukum perburuhan 
Indonesia mengemukakan bahwa dalam setiap perjanjian kerja selalu ada unsur perintah, yang menunjukkan bahwa kedudukan kedua belah pihak dalam perjanjian kerja tidaklah setara (Hernawan, 2014).

Kedudukan pengusaha selaku pemberi kerja selalu lebih tinggi ketimbang kedudukan pekerja/buruh dikarenakan oleh dua alasan, yakni alasan ekonomis dan alasan psikologis. Dilihat dari sisi ekonomis, jelas pengusaha memiliki kekuatan ekonomis yang lebih tinggi dibandingkan dengan pekerja/buruh. Sedangkan secara psikologis, pekerja/buruh cenderung menjadi pihak yang "lebih membutuhkan" karena secara faktual pengusaha adalah pihak yang memberikan pekerjaan dan juga membayarkan upah pekerja/buruh. Dikaitkan dengan hakekat hukum ketenagakerjaan secara umum, yakni untuk melindungi pekerja/buruh dari tindakan sewenang-wenang pengusaha, maka terlihat bahwa pekerja/buruh memang memiliki posisi yang lemah, oleh karenanya pihak pekerja/buruh perlu untuk dilindungi.

Posisi yang lebih lemah secara ekonomis maupun psikologis yang dimiliki oleh pekerja/buruh dalam perjanjian kerja ini berkesuaian dengan teori yang dikemukakan oleh Van Dunne tentang dua sifat perbuatan dalam penyalahgunaan keadaan. Menurut Van Dunne, penyalahgunaan keadaan bisa timbul karena dua sifat perbuatan, yakni adanya penyalagunaan keunggulan ekonomis, dan adanya penyalahgunaan keunggulan kejiwaan (Fidhayanti, 2019; Yunus, 2019). Dengan posisi pekerja/buruh yang lebih lemah secara ekonomis maupun psikologis (kejiwaan), kemungkinan terjadinya penyalahgunaan keadaan dalam pembuatan perjanjian kerja antara pekerja/buruh dan pengusaha menjadi terbuka lebar.

Lalu, apakah selama ini sudah ada penerapan konsep penyalahgunaan keadaan dalam konteks hukum ketenagakerjaan di Indonesia, khususnya dalam mekanisme penyelesaian perselisihan hubungan industrial? Berawal dari pertanyaan ini, penulis tertarik untuk melakukan penelitian terkait penerapan konsep penyalahgunaan keadaan sebagai alasan pembatalan perjanjian kerja di Pengadilan Hubungan Industrial. Rumusan masalah dalam penelitian ini adalah: Pertama. dapatkah konsep penyalahgunaan keadaan (undue influence) digunakan sebagai alasan pembatalan perjanjian kerja di Pengadilan Hubungan Industrial? Kedua, apakah telah ada kasus terkait perjanjian kerja di Pengadilan Hubungan Industrial yang menggunakan teori penyalahgunaan keadaan? Jika ada, bagaimana hakim melakukan penerapan konsep penyalahgunaan keadaan dalam putusannya?

\section{B. Metode Penelitian}

Penelitian ini menggunakan metode penelitian hukum yang bersifat normatif. Penelitian hukum normatif adalah penelitian yang hanya menggunakan sumber data-data sekunder, yaitu peraturan perundangundangan, putusan pengadilan, teori-teori hukum, dan doktrin ahli hukum terkemuka (Abdul Kadir, 2015). Metode analisis data yang digunakan dalam penelitian ini adalah metode kualitatif. Terdapat beberapa pendekatan yang akan digunakan dalam menganalisis permasalahan dalam penelitian ini, yakni melalui pendekatan undangundang (statute approach), pendekatan kasus (case approach), dan pendekatan konseptual (conceptual approach).

\section{Hasil dan Pembahasan}

1. Konsep Penyalahgunaan Keadaan (Undue Influence) sebagai Alasan Pembatalan Perjanjian Kerja di Pengadilan Hubungan Industrial

\section{a. Penyalahgunaan Keadaan Sebagai Alasan Pembatalan Perjanjian}

Penyalahgunaan keadaan atau biasa dikenal sebagai undue influence terdiri dari kata undue yang merujuk pada artian "tidak pantas atau tidak semestinya", dan influence berarti "pengaruh", sehingga undue influence 
secara harfiah diartikan sebagai "pengaruh yang tidak pantas atau tidak semestinya" . Pengaruh yang tidak pantas atau tidak semestinya inilah yang menyebabkan suatu kondisi yang di dalam bahasa Indonesia disebut sebagai "penyalahgunaan keadaan."

Seiring perkembangan ilmu hukum, khususnya hukum perdata, ajaran undue influence ternyata tidak hanya diterapkan oleh Inggris dan negaranegara yang menganut sistem common law, namun juga diterapkan oleh Belanda yang notabene menggunakan sistem civil law (Luik 17 juni 2002, noot Rechtsverwerking en rechtsmisbruik: een stand van zaken, in het bijzonder met betrekking tot de opeising van verwijlintresten, 2003). Hal ini dibuktikan dengan dicantumkannya penyalahgunaan keadaan, yang dalam bahasa Belanda disebut dengan istilah misbruik van omstandigheden, dalam Niew Burgerlijk Wetboek (NBW), Kitab Undang-Undang Hukum Belanda yang baru.

Misbruik van omstandigheden dicantumkan dalam Pasal 3:44 lid 1 NBW sebagai salah satu alasan dapat dibatalkannya suatu perjanjian. Pasal tersebut berbunyi: "Een rechtshandeling is vernietigbaar, wanneer zij door bedreiging, door bedrog of door misbruik van omstandigheden is totstandgekomen." Artinya, suatu perjanjian (perbuatan hukum) dapat dibatalkan jika adanya ancaman, tipuan, dan juga penyalahgunaan keadaan.

Ada anggapan yang menyatakan bahwa penyalahgunaan keadaan adalah suatu kondisi ketika isi dalam suatu perjanjian tidak dapat dibenarkan. Padahal, penyalahgunaan keadaan tidak semata-mata berkaitan dengan isi perjanjian. Bisa jadi isi suatu perjanjian tidak terlarang, namun ada sesuatu hal yang terjadi pada saat lahirnya perjanjian, yang menimbulkan kerugiaan pada salah satu pihak sehingga hal ini dapat dikategorikan sebagai penyalahgunaan keadaan (Bakker, 2016).

Penyalahgunaan keadaan pada dasarnya terdiri dari dua unsur, yakni menimbulkan kerugian yang sangat besar bagi salah satu pihak dan menyalahgunakan kesempatan. Penyalahgunaan kesempatan ini hanya dapat terjadi bilamana salah satu pihak yang mengadakan perjanjian memiliki keunggulan dibandingkan dengan pihak lainnya. Hal inilah yang mendasari Van Dunne mengklasifikasikan penyalahgunaan keadaan menjadi dua, yakni penyalahgunaan karena keunggulan ekonomis dan penyalahgunaan keadaan karena keunggulan kejiwaan (Bakker, 2016; van Eck, 1999). Suatu perjanjian dapat dikatakan mengandung penyalahgunaan keunggulan ekonomis jika: (1) salah satu pihak dalam perjanjian mempunyai keunggulan ekonomis terhadap pihak yang lain; dan (2) pihak lain terpaksa mengadakan perjanjian.

Poin kedua tentang pihak lain yang terpaksa mengadakan perjanjian ini mengarah pada teori kerugian subjektif yang dikemukakan oleh Van Dunne, sehingga diasumsikan bahwa pihak tersebut tidak akan menyepakati perjanjian bilamana pihak yang lain tidak mempunyai keunggulan ekonomis terhadapnya.

Untuk lebih memudahkan hakim dalam mengklasifikasikan apakah suatu perbuatan hukum mengandung penyalahgunaan keadaan ekonomis atau tidak, Van Dunne membuat empat pertanyaan: (1) apakah pihak yang satu mempuyai keunggulan ekonomis terhadap pihak yang lain?; (2) adakah kebutuhan mendesak untuk mengadakan perjanjian dengan pihak yang secara ekonomis lebih berkuasa, mengingat akan pasaran ekonomi dan posisi pasaran pihak lawan?; (3) apakah kontrak yang telah dibuat atau syarat yang telah disetujui tidak seimbang dalam menguntungkan pihak yang 
secara ekonomis lebih berkuasa dan dengan demikian perjanjian tersebut menjadi berat sebelah?; (4) Apakah keadaan berat sebelah semacam itu dapat dibenarkan oleh keadaan istimewa pada pihak yang secara ekonomis lebih berkuasa?

Jika dari empat pertanyaan di atas, tiga pertanyaan pertama dijawab dengan ya, dan pertanyaan terakhir dijawab dengan tidak, maka dapat diperkirakan sudah terjadi penyalahgunaan keadaan karena keunggulan ekonomis. Apabila suatu perjanjian telah terbukti mengandung unsur penyalahgunaan keadaan, maka perjanjian yang telah dibuat tersebut, termasuk syarat-syarat di dalamnya, sebagian atau seluruhnya dapat dibatalkan (Bakker, 2016).

\section{b. Penyalahgunaan Keadaan dalam Perjanjian Kerja}

Jika dilihat dari syarat-syarat sahnya perjanjian, maka pada dasarnya tidak ada perbedaan antara perjanjian kerja dengan perjanjian pada umumnya (Santoso \& T., 2012). Perjanjian kerja mensyaratkan adanya kesepakatan kedua belah pihak, kecakapan hukum, pekerjaan yang diperjanjikan sebagai objek, dan objek yang diperjanjikan tersebut tidak bertentangan dengan ketertiban umum, kesusilaan, dan Peraturan Perundangundangan yang berlaku. Artinya, secara umum ketentuan terkait pembatalan atau batalnya suatu perjanjian kerja mengikuti ketentuan perjanjian pada umumnya dalam KUH Perdata.

Namun, ada unsur-unsur yang secara spesifik harus dipenuhi dalam perjanjian kerja. Unsur-unsur tersebut antara lain: (a) adanya pekerjaan (arbeid); (b) adanya upah tertentu (loan); (c) di bawah perintah (gezagsverhouding); dan (d) dalam waktu (tijd) yang ditentukan (Rohanawati \& Wicaksono, 2018). Unsur Pertama, pekerjaan, merupakan unsur pokok yang harus ada dalam perjanjian kerja. Pekerjaan diberikan dan ditentukan oleh pemberi kerja (pengusaha), serta wajib dilakukan secara pribadi oleh pekerja (Alexander Putra, 2017).

Unsur kedua, yakni upah, merupakan hak dari pekerja yang telah melaksanakan pekerjaan sebagaimana yang diberikan oleh pemberi kerja atau pengusaha. Upah merupakan kewajiban pengusaha kepada pekerja, dan dapat dikatakan sebagai bentuk kontra prestasi dari pemberi kerja atas prestasi pekerja berupa melaksanakan pekerjaan (Adawiyah, 2016; Trimaya, 2014).

Unsur ketiga adalah perintah. yang berarti bahwa dalam melakukan pekerjaan yang diperjanjikan, pekerja harus tunduk pada perintah orang lain, dalam hal ini adalah majikan/pengusaha. Artinya, seorang pekerja dalam melaksanakan pekerjaannya akan berada di bawah wibawa orang lain, yaitu si majikan (Santoso \& T., 2012). Unsur perintah ini merupakan perwujudan fakta kedudukan pekerja dan pengusaha yang tidak setara. Perbedaan kedudukan pekerja dan pengusaha ini tidak hanya memberi konsekuensi pada saat pekerjaan dilangsungkan, namun juga sejak perjanjian kerja dibuat (Hernawan, 2014). Kedudukan pekerja yang lemah seringkali memposisikan mereka sebagai pihak yang pasif dalam pembuatan perjanjian kerja, karena seakan-akan merekalah yang membutuhkan untuk diberi pekerjaan oleh pengusaha, bukan sebaliknya.

Lebih lanjut, jika ditinjau dari asas keseimbangan para pihak dalam pembuatan perjanjian, hal ini menyebabkan konsep perjanjian kerja berbeda dengan konsep perjanjian pada umumnya yang bercirikan adanya keseimbangan para pihak (Santoso \& T., 2012). Menurut Otto Kahn-Freud, seorang bapak hokum perburuhan dunia, dalam perjanjian kerja terdapat ciri penundukan diri (submission), 
subordinasi (subordination), dan ketidaksamaan daya tawar (inequality of bargaining power). (Dukes, 2008, 2009, 2015)

Hal ini terbukti dari banyaknya perjanjian kerja yang dibuat dalam bentuk perjanjian standar yang isinya dibuat secara sepihak oleh pihak pengusaha sebagai pemberi kerja (Roesli et al., 2019; Yunus, 2019). Pekerja hanya diberikan pilihan untuk menyetujui atau tidak menyetujui perjanjian kerja tersebut, tanpa diberikan kesempatan untuk mendiskusikan pasal-pasal dalam perjanjian kerja yang akan menjadi dasar hubungan kerja antara pekerja dengan pemberi kerja tersebut. Artinya, kedudukan superior pengusaha sebagai pemberi kerja memang telah tampak sejak awal pembuatan perjanjian kerja. Imbasnya, dalam pelaksanaan hubungan kerja pun kedudukan antara pekerja/buruh dengan pengusaha selaku pemberi kerja seringkali tidak seimbang.

Menurut Guy Davidov, ketidakseimbangan kedudukan para pihak dalam hubungan kerja juga dicirikan oleh adanya ketergantungan pekerja/buruh pada hubungan berdasarkan kepentingan ekonomi, sosial, dan psikologi (Davidov, 2005; Davidov \& Langille, 2011). Hal ini berkaitan dengan pendapat Van Dunne, yang menyebutkan bahwa sebuah perjanjian memiliki potensi penyalahgunaan keadaan ekonomis ketika salah satu pihak dalam perjanjian memiliki keunggulan ekonomis terhadap pihak yang lain. Terdapat empat pertanyaan yang bisa menjadi parameter apakah dalam suatu perjanjian telah terjadi penyalahgunaan keadaan keunggulan ekonomis atau tidak (Ceil, 2015; Hough et al., 2018; Stone et al., 2018). Keempat pertanyaan ini akan dikontekstualisasikan dengan perjanjian kerja, sehingga dapat terlihat apakah secara teoritis dalam suatu perjanjian kerja berpotensi terjadi penyalahgunaan keadaan karena keunggulan ekonomis.

Pertanyaan pertama adalah "apakah pihak yang satu mempunyai keunggulan ekonomis terhadap yang lain?" Tidak dapat dipungkiri bahwa dalam kaitannya dengan perjanjian kerja, jelas terlihat bahwa pengusaha atau pemberi kerja memiliki keunggulan ekonomis terhadap pekerja/buruh. Keunggulan ekonomis ini dikonkritkan dengan posisi pengusaha yang selain memberikan pekerjaan juga sekaligus sebagai pemberi upah. Sehingga jelas bahwa dalam perjanjian kerja, salah satu pihak memiliki keunggulan ekonomis terhadap pihak yang lain.

Pertanyaan kedua adalah, "adakah kebutuhan mendesak untuk mengadakan kontrak dengan pihak yang ekonomis lebih kuasa, mengingat akan pasaran ekonomi dan posisi pasaran pihak lawan?" Di Indonesia, kebutuhan calon pekerja terhadap pekerjaan yang diberikan oleh pengusaha sangatlah tinggi, karena jumlah pekerjaan yang lebih sedikit dibandingkan dengan jumlah pencari pekerjaan. Situasi inilah yang menimbulkan adanya kebutuhan mendesak bagi pekerja/buruh untuk membuat perjanjian kerja dengan pengusaha, mengingat perjanjian kerja merupakan syarat mutlak terjadinya hubungan kerja.

Pengusaha sebagai pemberi kerja memiliki posisi yang lebih diuntungkan karena calon pekerja/buruh berada diposisi yang lebih membutuhkan. Melihat data dan pasaran ekonomi saat ini, jelas terlihat bahwa dalam konteks perjanjian kerja, pekerja/buruh yang merupakan salah satu pihak dalam perjanjian kerja memiliki posisi yang terdesak untuk mengadakan perjanjian dengan pihak lain, yang dalam hal ini adalah pengusaha.

Pertanyaan ketiga adalah "apakah kontrak yang telah disetujui tidak seimbang dalam menguntungkan pihak 
yang ekonomis lebih kuasa dan dengan demikian berat sebelah?" Pertanyaan ini tentu saja tidak dapat digeneralisasikan terhadap semua perjanjian kerja. Tiaptiap perjanjian kerja memiliki kekhususan terkait isi dalam pasal-pasal yang tercantum di dalamnya, sesuai dengan penerapan asas kebebasan berkontrak.

Meski begitu, perlu diperhatikan bahwa salah satu unsur dari perjanjian kerja adalah adanya unsur perintah, yang menempatkan pekerja pada posisi harus melakukan pekerjaan di bawah wibawa pemberi kerja. Konsekuensi dari unsur ini adalah tiap-tiap pekerjaan yang dilakukan oleh pekerja dalam suatu perjanjian kerja haruslah memberikan keuntungan bagi pihak pemberi kerja. Dari ciri ini dapat terlihat bahwa perjanjian kerja pada umumnya memberikan keuntungan yang lebih bagi pemberi kerja dibandingkan kepada pekerja/buruh.

Hipotesis ini kemudian juga didukung oleh fakta bahwa sebagian besar perjanjian kerja di perusahaanperusahaan saat ini dibuat dalam bentuk perjanjian standar. Perjanjian standar atau perjanjian baku secara sederhana merupakan perjanjian yang isinya dibakukan dan dituangkan dalam bentuk formulir (Jamilah, 2012; Sembiring, 1999). Menurut Sudikno Mertokusumo, perjanjian standar adalah perjanjian yang dibuat secara apriori menguntungkan salah satu pihak, karena pihak yang satu mempunyai kedudukan lebih unggul baik secara ekonomis maupun psikologis dari pihak yang lain (Hidayat, 2019).

Melihat karakteristik dari perjanjian standar yang banyak digunakan dalam perjanjian kerja, maka terlihat bahwa secara teori, isi dari suatu perjanjian kerja tidak akan berimbang. Ketidakseimbangan dalam perjanjian kerja ini menguntungkan pihak yang secara ekonomis lebih berkuasa, yakni pengusaha, sehingga menjadi perjanjian yang berat sebelah (Hernawan, 2014). Sehingga jawaban dari pertanyaan ketiga adalah iya.

Menurut Van Dunne, apabila tiga pertanyaan dalam teorinya dijawab dengan ya, maka dapat diperkirakan telah terjadi penyalahgunaan keadaan, sehingga perjanjian yang telah dibuat beserta syarat-syarat di dalamnya, sebagian atau seluruhnya dapat dibatalkan (Bakker, 2016; van Eck, 1999). Perjanjian kerja sebagaimana telah diuraikan di atas telah memenuhi 3 pertanyaan ini, sehingga dapat disimpulkan bahwa dalam perjanjian kerja terdapat potensi besar untuk terjadinya penyalahgunaan keadaan karena keunggulan ekonomis.

\section{Kasus terkait Perjanjian Kerja yang Menggunakan Teori Penyalahgunaan Keadaan (Undue Influence) di Pengadilan Hubungan Industrial}

Setelah dilakukan penelusuran oleh Penulis, ditemukan bahwa telah ada beberapa perkara terkait hubungan kerja di Pengadilan Hubungan Industrial yang dalam pertimbangan hukumnya menggunakan teori penyalahgunaan keadaan. Salah satu contohnya terlihat dalam Putusan Pengadilan Hubungan Industrial Bandung Nomor 59/G/2014/PHI.PN.BDG.

Perkara ini merupakan Perselisihan Hubungan Industrial terkait Pemutusan Hubungan Kerja antara Jaenudin Samsu Alam, Hendra Priana, Arif Rachman Muslim, Firman Syah, dan Dicky Hardiansyah (Para Penggugat) melawan PT. FCC Indonesia (Tergugat). Para Penggugat merupakan pekerja di PT. FCC Indonesia dengan status yang berbeda-beda. Hendra Priana, Arif Rachman Muslim, dan Dicky Hardiyansyah berstatus pekerja tetap, sedangkan Jaenudin Samsu Alam dan Firman Syah berstatus pekerja dengan Perjanjian Kerja Waktu Tertentu.

Para Penggugat ketika masih menjadi pekerja telah dituduh melakukan perbuatan penggelapan hasil produksi, meskipun tuduhan ini menurut Para Penggugat belum 
bisa dibuktikan menurut hukum. Akibat dari tuduhan ini, pada tanggal 20 Maret 2013, Para Penggugat di bawah tekanan oleh pihak Tergugat diminta untuk menandatangani surat pengunduran diri dengan alasan kepentingan keluarga. Karena hal ini, maka Para Penggugat menempuh mekanisme penyelesaian perselisihan hubungan industrial yang diawali dengan bipartid dan mediasi, namun karena tidak ada titik temu maka Para Penggugat kemudian mengajukan gugatan ke Pengadilan Hubungan Industrial. Dalam gugatannya, para penggugat meminta majelis hakim menghukum tergugat untuk membayar uang pesangon dan upah sesuai ketentuan perundang-undangan.

Yang menarik, para penggugat dalam kasus ini pada awalnya tidak mendalilkan mengenai kemungkinan terjadinya penyalahgunaan keadaan dalam gugatannya. Namun, dalam pertimbangan majelis hakim, salah satu anggota majelis hakim, yakni Hakim H. Asep Maulana SY, S.H., yang berinisiatif membahas mengenai kemungkinan adanya penyalahgunaan keadaan dalam kasus ini.

Hakim Asep dalam pertimbangannya menyebutkan bahwa menimbang keterangan saksi dan surat bukti di persidangan, Para penggugat (pekerja) melakukan penandatanganan surat penguduran diri karena merasa tertekan karena dituduh melakukan penggelapan di perusahaan, dan disuruh untuk mengundurkan diri oleh Tergugat (pihak perusahaan). Hakim juga menimbang bahwa form surat pengunduran diri sudah disediakan sendiri oleh pihak perusahaan.

Lebih lanjut, hakim menimbang bahwa tindakan Tergugat yang menawarkan atau menyuruh Para Penggugat untuk mengundurkan diri dari perusahaan dengan memberikan form surat pengunduran diri kepada Para Penggugat adalah suatu hal yang sangat tidak layak dan tidak adil untuk Para Penggugat. Seharusnya Tergugat menunggu proses laporan tersebut berjalan dan lebih jelas terlebih dahulu. Siapa yang terlibat dan siapa yang tidak terlibat, dan itu semua harus dilakukan sesuai dengan prosedur dan siatem hukum yang berlaku, demi untuk menghormati asas preassumtion of innocent terhadap Para Penggugat.

Karena hal ini, maka hakim kemudian menimbang bahwa dalam hukum Perdata, berdasarkan Pasal 1321 dan Pasal 1449 KUHPerdata, cacat kesepakatan atau cacat kehendak dapat terjadi karena kekhilafan, kesesatan, penipuan dan paksaan. Tetapi, dalam hukum Perdata, menurut teori kehendak (Wilstheorie), juga dikenal adanya istilah Penyalahgunaan Keadaan dalam Kehendak (Misbruik van Omstadigheden). Penyalahgunaan sebagai salah satu syarat kehendak berkembang, oleh karena adanya perkembangan beberapa peristiwa hukum dalam hukum perikatan/perjanjian. Penyalahgunaan keadaan sendiri dapat terjadi apabila orang mengetahui atau seharusnya mengerti bahwa pihak lain karena suatu keadaan khusus seperti keadaan darurat, tidak dapat berpikir panjang, keadaan jiwa abnormal, atau tidak berpengalaman tergerak untuk melakukan sesuatu perbuatan hukum meskipun ia tahu atau seharusnya mengerti bahwa seharusnya ia dapat mencegahnya atau tidak melakukannya.

Lebih lanjut, hakim dalam perkara ini menjelaskan bahwa penyalahgunaan keadaan kehendak dapat dibagi dalam dua jenis, yaitu penyalahgunaan keadaan karena keunggulan ekonomi salah satu pihak terhadap pihak lain (economische overwicht) dan penyalahgunaan keadaan karena keunggulan psikologis satu pihak terhadap pihak lain (geestelijke overwicht).

Indikator dan prasyarat yang dapat menimbulkan terjadinya penyalahgunaan kehendak karena keunggulan ekonomi, diantaranya adalah: (a) Satu pihak dalam perjanjian lebih unggul di bidang ekonomi dari pihak lainnya; dan (b) Pihak lain terdesak untuk melakukan perjanjian dengan yang bersangkutan. Sedangkan indikator dan prasyarat yang dapat menimbulkan terjadinya penyalahgunaan kehendak karena keunggulan psikologis, diantaranya adalah: (a) adanya ketergantungan satu pihak yang lemah yang disalahgunakan oleh pihak yang 
lebih unggul secara psikologis terhadap pihak lainnya; dan (b) ada keunggulan psikologis luar biasa satu pihak dengan pihak lainnya.

Hakim kemudian mengaitkan dengan fakta di kasus ini, bahwa perjanjian sepihak adalah perjanjian yang membebankan prestasi hanya pada satu pihak. Berdasarkan pada definisi tersebut, maka form pernyataan pengunduran diri sebagaimana yang terdapat di perusahaan tergugat adalah salah satu bentuk perjanjian sepihak. Walau hanya membebankan kewajiban untuk melakukan satu prestasi bagi buruh/pekerja, tetapi hal tersebut berakibat hukum bagi kedua belah pihak, baik buruh/pekerja maupun perusahaan.

Hakim kemudian menimbang bahwa dilihat dari kondisi dan fakta yang terjadi, adanya pemberian dan penawaran form pengunduran diri dari Tergugat kepada Para Penggugat adalah salah satu contoh penyalahgunaan keadaan dalam teori kehendak tersebut, sehingga walaupun hal itu telah dilakukan oleh Para Penggugat, maka pernjanjian atau pernyataan tersebut dapat dibatalkan secara hukum oleh Para penggugat bila dirasakan merugikan dan digugat kemudian oleh Para Penggugat. Sehingga dengan demikian, Hakim Asep berpendapat bahwa PHK yang dilakukan Tergugat dengan alasan mengundurkan batal demi hukum.

Pertimbangan yang diberikan oleh Hakim Asep dalam kasus ini menurut penulis adalah sebuah fenomena hukum yang sangat menarik. Pertimbangan hakim di atas merupakan contoh penggunaan doktrin penyalahgunaan keadaan (undue influence) dalam proses pengambilan keputusan hakim di Pengadilan Hubungan Industrial, bahkan ketika penggugat tidak secara eksplisit mendalilkan kemungkinan adanya penyalahgunaan keadaan, Hakim Pengadilan Hubungan Industrial menggunakan teori undue influence karena beranggapan bahwa situasi yang dihadapi oleh para penggugat dalam kasus tersebut berpotensi dikategorikan sebagai penyalahgunaan keadaan.
Hakim dalam perkara ini berpendapat bahwa dilihat dari kondisi dan fakta yang terjadi adanya pemberian dan penawaran form pengunduran diri dari Tergugat kepada Para Penggugat adalah salah satu contoh penyalahgunaan keadaan dalam teori kehendak, sehingga walaupun hal itu telah dilakukan oleh Para Penggugat, maka perjanjian atau pernyataan tersebut dapat dibatalkan secara hukum oleh Para penggugat bila dirasakan merugikan dan digugat kemudian oleh Para Penggugat. Dengan kata lain, Hakim Asep menyatakan bahwa seharusnya PHK yang dilakukan Tergugat dengan alasan mengundurkan diri dapat dinyatakan batal demi hukum.

Sayangnya, kedua anggota hakim lain dalam perkara ini tidak sependapat dengan pertimbangan hukum yang diberikan oleh Hakim Asep. Pada akhirnya, Pengadilan Hubungan Industrial Bandung mengadili bahwa gugatan Penggugat atas nama Jaenudin Samsu Alam dan Firmansyah tidak dapat diterima, dan gugatan Penggugat atas nama Hendra Priana, Arif Rachman Muslim, dan Dicky Hardiansyah ditolak untuk seluruhnya. Selain itu, Majelis Hakim juga menyatakan bahwa Hubungan Kerja antara Tergugat dan Para Penggugat atas nama Hendra Priana, Arif Rachman Muslim, dan Dicky Hardiansyah putus karena pengunduran diri. Pendapat hukum yang diberikan Hakim Asep pun menjadi dissenting opinion dalam perkara ini.

Meski begitu, penulis tetap berpendapat bahwa perkara ini merupakan salah contoh yang sangat baik untuk merepresentasikan penggunaan teori penyalahgunaan keadaan dalam penyelesaian perkara di Pengadilan Hubungan Industrial. Penerapan teori penyalahgunaan keadaan yang dilakukan oleh Hakim Asep adalah sebuah bukti bahwa Hakim Pengadilan Hubungan Industrial telah menerima penggunaan doktrin ini dalam penyelesaian masalahmasalah terkait perjanjian kerja, khususnya dalam kaitannya dengan pemutusan hubungan kerja. Hal ini merupakan hal yang patut diapresiasi, karena di masa yang akan datang dapat menjadi sebuah terobosan 
hukum yang bermanfaat dalam konteks penyelesaian kasus-kasus hubungan industrial.

\section{Simpulan}

Kajian dalam penelitian ini menunjukkan bahwa terdapat potensi besar terjadinya penyalahgunaan keadaan dalam perjanjian kerja. Hal ini terjadi karena posisi para pihak dalam perjanjian kerja, yakni pengusaha dan pekerja/buruh secara ekonomis sangatlah tidak berimbang. Selain itu, banyaknya perjanjian kerja yang dibuat dalam bentuk perjanjian standar juga menjadi alasan adanya potensi penyalahgunaan keadaan dalam perjanjian kerja. Secara teoritis, apabila ditemukan terjadinya penyalahgunaan keadaan dalam perjanjian kerja, maka konsep penyalahgunaan keadaan (undue influence) dapat digunakan sebagai alasan pembatalan perjanjian kerja. Hal ini dapat diputuskan melalui mekanisme penyelesaian perselisihan hubungan industrial, mulai dari bipartid, mediasi, konsiliasi, sampai dengan di Pengadilan Hubungan Industrial.

Pengadilan Hubungan Industrial telah beberapa kali menangani kasus terkait dengan ajaran penyalahgunaan keadaan. Penulis menganalisis satu putusan secara spesifik, yakni Putusan Pengadilan Hubungan Industrial Bandung Nomor 59/G/2014/PHI.PN.BDG. Dalam putusan ini, majelis hakim menjadikan doktrin penyalahgunaan keadaan sebagai bahan pertimbangan dalam mengambil keputusan. Meskipun pada akhirnya Majelis Hakim akhirnya memutuskan bahwa tidak terjadi penyalahgunaan keadaan dalam perkara ini, penerapan teori penyalahgunaan keadaan di putusan ini merupakan bukti bahwa Hakim Pengadilan Hubungan Industrial telah menerima penggunaan doktrin ini dalam penyelesaian masalah-masalah terkait perjanjian kerja, khususnya dalam kaitannya dengan pemutusan hubungan kerja.

\section{DAFTAR PUSTAKA}

Abdul Kadir, M. (2015). Hukum Dan Penelitian Hukum. Bandung: PT. Citra Aditya Bakti. https://doi.org/10.25041/fiatjustisia.v8n o1.283

Adawiyah, N. F. (2016). Analisis Yuridis Peraturan Pemerintah Nomor 78 Tahun 2015 Tentang Pengupahan Ditinjau Dari Perspektif Perlindungan Pekerja. Hukum.

Adhyaksa, G. (2016). Penerapan Asas Perlindungan Yang Seimbang Menurut Kuhperdata Dalam Pelaksanaan Perjanjian Kerja Untuk Waktu Tertentu Dihubungkan Dengan Undang-Undang Nomor 13 Tahun 2003 Tentang Ketenagakerjaan. Unifikasi: Jurnal Ilmu Hukum. https://doi.org/10.25134/unifikasi.v3i2. 411

Alexander Putra, C. V. (2017). Urgensi Klausula Definisi Dalam Perjanjian Kerja. Kertha Patrika. https://doi.org/10.24843/kp.2017.v39.i0 1.p05

Badrulzaman, M. D. (1981). Hak-Hak Azasi Manusia Menurut Undang-Undang Dasar 1945 Dan Penjabarannya Di Dalam Hukum Perjanjian Nasional. Jurnal Hukum \& Pembangunan. https://doi.org/10.21143/jhp.vol11.no1. 837

Bakker, P. S. (2016). Vernietiging van overeenkomsten op grond van laesio enormis, dwaling of misbruik van omstandigheden. Maandblad Voor Vermogensrecht.

https://doi.org/10.5553/mvv/157457672 016014001001

Ceil, C. (2015). Contractual Free Will: Doctrines of Economic Duress \& Undue Influence. SSRN Electronic Journal.

https://doi.org/10.2139/ssrn.2596998 
Davidov, G. (2005). Who is a worker? In Industrial Law Journal. https://doi.org/10.1093/ilj/34.1.57

Davidov, G., \& Langille, B. (2011). The Idea of Labour Law. In The Idea of Labour Law. https://doi.org/10.1093/acprof:oso/9780 199693610.001 .0001

Dukes, R. (2008). Constitutionalizing employment relations: Sinzheimer, Kahn-Freund, and the role of labour law. In Journal of Law and Society. https://doi.org/10.1111/j.14676478.2008.00442.x

Dukes, R. (2009). Otto Kahn-Freund and Collective Laissez-Faire: An Edifice without a Keystone? Modern Law Review. https://doi.org/10.1111/j.14682230.2009.00741.x

Dukes, R. (2015). Wedderburn and the theory of labour law: Building on KahnFreund. Industrial Law Journal. https://doi.org/10.1093/indlaw/dwv015

Enonchong, N. (1996). Contract Damages for Injury to Reputation. The Modern Law Review. https://doi.org/10.1111/j.14682230.1966.tb02102.x

Fidhayanti, D. (2019). Penyalahgunaan Keadaan (Misbruik Van Omstandigheden) Sebagai Larangan Dalam Perjanjian Syariah. Jurisdictie. https://doi.org/10.18860/j.v9i2.5076

Hernawan, A. (2014). Industrial Relations In The Perspective Of Justice Theory By John Rawls. Mimbar Hukum - Fakultas Hukum Universitas Gadjah Mada. https://doi.org/10.22146/jmh.16042

Hernoko, A. Y., \& Anand, G. (2017). The application of circumstance abuse doctrine (Misbruik Van Omstandigheden) on judicial practice in Indonesia. Journal of Advanced Research in Law and Economics. https://doi.org/10.14505/jarle.v8.7(29).1 0
Hidayat, A. (2019). Kekuatan Mengikat Klausul Eksonerasi Dalam Perjanjian Baku Dihubungkan Dengan Asas Kebebasan Berkontrak. Syiar Hukum: Jurnal Ilmu Hukum. https://doi.org/10.29313/sh.v16i2.5354

Hough, T., Kirk, E., Hough, T., \& Kirk, E. (2018). Duress and undue influence. In Contract Law. https://doi.org/10.4324/9781315678283 $-10$

Jamilah, L. (2012). Asas Kebebasan Berkontrak Dalam Perjanjian Standar Baku. Syiar Hukum, FH UNISBA.

Nurhayati, B. R. (2019). Penyalahgunaan Keadaan Sebagai Dasar Pembatalan Perjanjian. Jurnal Komunikasi Hukum (JKH). https://doi.org/10.23887/jkh.v5i1.16752

Rahman, T., Innaka, A., Hernawan, A., \& Pramuwardhani, D. (2011). Asas Kebebasan Berkontrak Dan Asas Kepribadian Dalam Kontrak-Kontrak Outsourcing. Mimbar Hukum, 20(3), 431-645. https://doi.org/10.22146/jmh. 16178

Roesli, M., Sarbini, S., \& Nugroho, B. (2019). Kedudukan Perjanjian Baku Dalam Kaitannya Dengan Asas Kebebasan Berkontrak. DiH: Jurnal Ilmu Hukum. https://doi.org/10.30996/dih.v15i1.2260

Rohanawati, A. N., \& Wicaksono, D. A. (2018). Kesetaraan Dalam Perjanjian Kerja Dan Ambiguitas Pertimbangan Hukum Mahkamah Konstitusi. Jurnal Yudisial. https://doi.org/10.29123/jy.v11i3.307

Santoso, B., \& T., R. (2012). Eksistensi Asas Kebebasan Berkontrak Dalam Perjanjian Kerja. Arena Hukum. https://doi.org/10.21776/ub.arenahukum .2012 .00503 .6

Sembiring, S. (1999). Pencantuman Asas Kewajaran dalam Kontrak Standar (Perjanjian Baku) sebagai Salah Satu 
Upaya Melindungi Konsumen. Jurnal Hukum IUS QUIA IUSTUM. https://doi.org/10.20885/iustum.vol6.iss 12.art10

Stone, R., Devenney, J., Stone, R., \& Devenney, J. (2018). Undue influence. In Text, Cases and Materials on Contract Law. https://doi.org/10.4324/9781315692838 $-11$

Trimaya, A. (2014). Pemberlakuan Upah Minimum Dalam Sistem Pengupahan Nasional Untuk Meningkatkan Kesejahteraan Tenaga Kerja. Aspirasi. van Eck, M. (1999). Misbruik van omstandigheden bij de beëindigingsovereenkomst. Bulletin Arbeid, Sociale Zekerheid \& Recht.

Luik 17 juni 2002, noot Rechtsverwerking en rechtsmisbruik: een stand van zaken, in het bijzonder met betrekking tot de opeising van verwijlintresten, Tijdschrift voor Belgisch Burgerlijk Recht (2003).

Yunus, A. (2019). Penyalahgunaan Keadaan dalam Bentuk Perjanjian Baku. Kanun : Jurnal Ilmu Hukum. https://doi.org/10.24815/kanun.v21i2.12 854 